\title{
Viral Protein Synthesis in Mouse Hepatitis Virus Strain A59- Infected Cells: Effect of Tunicamycin
}

\author{
PETER J. M. ROTTIER,* MARIAN C. HORZINEK, AND BERNARD A. M. VAN DER ZEIJST \\ Institute of Virology, Veterinary Faculty, State University of Utrecht, Utrecht, The Netherlands
}

Received 18 May 1981/Accepted 10 July 1981

\begin{abstract}
We identified eight protein species in virions of mouse hepatitis virus strain A59. Based on their sizes, prosthetic groups, and locations in virions, these proteins were designated gp180/E2, gp90/E2, pp54/N, gp26.5/E1, gp25.5/E1, $\mathrm{p} 24 / \mathrm{E} 1, \mathrm{p} 22 / \mathrm{X}$, and $\mathrm{p} 14.5 / \mathrm{Y}$. The positions of the last two proteins in virions are not known. Host protein synthesis in Sac(-) cells infected with mouse hepatitis virus strain A59 was inhibited, and the following novel proteins appeared: gp150, gp90, p54, gp26.5, gp25.5, p24, p22, and p14.5. Except for gp150, these polypeptides all co-electrophoresed with mouse hepatitis virus strain A59 structural proteins. In addition, all of these proteins could be immunoprecipitated with a convalescent mouse serum or a rabbit antiserum raised against purified disrupted virus. After a 15-min pulse of infected cells with radioactive amino acids at $7 \mathrm{~h}$ postinfection, gp90 was not detected, whereas gp26.5 and gp25.5 were only labeled to a small extent. During a subsequent chase period gp150 was processed to gp90, whereas the radioactivity in gp26.5 and gp25.5 increased concomitantly with a reduction of label in p24. Tunicamycin, an antibiotic which inhibits the synthesis of glycopeptides bearing $\mathrm{N}$ glycosidically linked oligosaccharides, prevented the appearance of gp150 in mouse hepatitis virus strain A59-infected cells. Instead, a 110,000 -dalton protein accumulated. In contrast, the syntheses of the smaller viral glycoproteins gp26.5 and gp25.5 were resistant to this drug, indicating that these glycosylations were of the $\mathrm{O}$ glycosidical type. Although the production of infectious virus in tunicamycin-treated cells was inhibited by more than $99 \%$, release of noninfectious viral particles continued. An analysis of these particles revealed that they lacked the peplomeric glycoproteins gp90/E2 and gp180/E2. Obviously, although the surface projections were not essential for budding of virus particles from the cells, they were required for infectivity.
\end{abstract}

Recently, it has become clear that the members of the Coronaviridae are a group of positivestranded RNA viruses with a unique multiplication strategy. Both avian infectious bronchitis virus $(11,12)$ and mouse hepatitis virus strain A59 (MHV-A59) (10) induce multiple subgenomic RNAs in host cells. Since these RNAs are polyadenylated and since the MHV-A59-specific RNAs occur in polysomes (10), they probably function as virus-specific messengers. Indeed, we showed that in the case of MHV-A59 at least three of these RNAs can be translated into products related to viral structural proteins (6). To relate these products to the proteins made during virus replication, we studied the synthesis of virus-specific intracellular proteins.

Data on the synthesis of coronavirus-specific proteins in infected cells are scarce. Four major viral polypeptides were identified by Anderson et al. (1) in cells infected with the murine coronavirus strains JHM and MHV-3, and Bond et al. (2) reported the detection of nine virus-specific polypeptides after infection of cells with strains
JHM and A59. In all cases the following two protein species clearly predominated: (i) a glycopeptide with a molecular weight of approximately 150,000 , which was thought to be identical to E2, the structural protein present in the virion peplomers (16), and (ii) a polypeptide with a molecular weight of about 60,000 , which probably represented the viral nucleocapsid protein $(1,2)$. In addition, one or two lower-molecularweight virus-specific species were found; these were presumed to be related to $\mathrm{E} 1$, the virion membrane glycoprotein (16). The possible significance of the other proteins that were induced in cells upon infection by strains JHM and A59 (2) is not known. In a very recent paper Siddell et al. (9) presented data on intracellular protein synthesis in coronavirus JHM-infected cells. These workers detected a number of virus-specific proteins, which were characterized by comparison with virion proteins, immunoprecipitation, and two-dimensional gel electrophoresis. Pulse-chase experiments revealed the occurrence of precursor-product relationships among 
some of them. The results of Siddell et al. on strain JHM are in very close agreement with our data on MHV-A59. We compare specific data on these two viruses below.

\section{MATERIALS AND METHODS}

Cells and virus. MHV-A59 was grown in Sac(-) cells. One-step virus growth was achieved by an infection and incubation procedure described previously (6). MHV-A59 was purified from the culture medium of the cells by the method of Spaan et al. (10).

Radioactive labeling of intracellular proteins. Monolayer cultures of MHV-A59-infected Sac(-) cells grown in 35-mm tissue culture dishes were washed twice with phosphate-buffered saline at the times indicated below and then incubated further in methionine-deficient minimal essential medium supplemented with 5\% fetal calf serum or in minimal essential medium containing $2 \%$ fetal calf serum and $1 / 10$ the normal concentrations of lysine, tyrosine, leucine, and phenylalanine. At the start of the incubation, $L-\left[{ }^{35} \mathrm{~S}\right]-$ methionine $(1,060 \mathrm{Ci} / \mathrm{mmol}$; The Radiochemical Centre, Amersham, England) or ${ }^{3} \mathrm{H}$-amino acids (a mixture of lysine, tyrosine, leucine, phenylalanine, and proline; 65 to $150 \mathrm{Ci} / \mathrm{mmol}$; The Radiochemical Centre) were added as indicated below. In pulse-chase experiments the cells were labeled with ${ }^{3} \mathrm{H}$-amino acids, washed with phosphate-buffered saline, and then incubated at $37^{\circ} \mathrm{C}$ in Dulbecco modified minimal essential medium containing $10 \%$ fetal calf serum and four times the standard concentrations of all amino acids. To label glycoproteins, cells were incubated in minimal essential medium containing $1 / 10$ the standard amount of glucose, $2 \%$ fetal calf serum, and D-[2$\left.{ }^{3} \mathrm{H}\right]$ mannose (16 Ci/mmol; The Radiochemical Centre) or D- $\left[6-{ }^{3} \mathrm{H}\right]$ glucosamine hydrochloride $(38 \mathrm{Ci} / \mathrm{mmol}$; The Radiochemical Centre). Cell lysates were prepared as described previously (6).

Immunoprecipitation and gel electrophoresis of proteins. These procedures have been described previously (6). Briefly, samples of the cleared cell lysates $(20$ to $40 \mu \mathrm{l})$ were mixed with 7 to $10 \mu \mathrm{l}$ of antiserum obtained from rabbits immunized against purified MHV-A59 or from mice that had gone through an MHV-A59 infection. After overnight incubation at $4^{\circ} \mathrm{C}$, the immune complexes were adsorbed to protein A-Sepharose, washed, and dissolved in electrophoresis sample buffer. The samples were heated or electrophoresed directly without heating in 12.5 or $15 \%$ polyacrylamide gels.

\section{RESULTS}

MHV-A59 structural proteins. Virus purified from the culture fluid of MHV-A59-infected $\mathrm{Sac}(-)$ cells was analyzed by electrophoresis in a sodium dodecyl sulfate-polyacrylamide gel. Seven proteins with molecular weights of $180,000,90,000,54,000,26,500,25,500,24,000$, and 22,000 were resolved (Fig. 1). Of these, the 90,000 - and 180,000-dalton proteins represented the two molecular species of the peplomeric protein (17). Additional high-molecular-weight species were sometimes observed (Fig. 1). We assumed that these proteins were multimers of the 90,000-dalton polypeptide. An additional 14,500-dalton protein was often observed on autoradiographs after longer exposures, shown below. Four of the seven proteins incorporated $\left[{ }^{3} \mathrm{H}\right]$ glucosamine. The 54,000 -dalton protein has been shown previously to be phosphorylated $(6$, 13). Based on these properties and for the reasons discussed below, we designated these proteins gp180/E2, gp90/E2, pp54/N, gp26.5/E1, gp25.5/E1, p24/E1, p22/X, and p14.5/Y, where $\mathrm{N}, \mathrm{E1}$, and E2 refer to the locations of the proteins in virions (nucleocapsid, envelope membrane, and envelope surface projections, resnectively) $(17,18)$.

As far as the $180,000-, 90,000$-, and 54,000 dalton proteins were concerned, our findings were in agreement with previously described data. However, only one lower-molecular-weight MHV-A59 glycoprotein was reported previously, whereas three polypeptide species (molecular weights, $24,000,25,500$, and 26,500 ) were resolved under our experimental conditions. These proteins were always readily detectable if the protein samples were not heated before electrophoresis, since heating led to aggregation, as described previously (16). These proteins were also labeled in a lactoperoxidase-catalyzed iodination reaction with purified intact virus (data not shown). The detection of the 22,000-dalton species and especially the 14,500-dalton species required virus of high specific radioactivity or long exposures of autoradiographs. Occasionally, we observed an additional protein that had a molecular weight of about 27,500 and could be labeled with $\left[{ }^{3} \mathrm{H}\right]$ glucosamine.

MHV-A59-8pecific intracellular protein synthesis. MHV-A59-infected cells were labeled with $\left[{ }^{35} \mathrm{~S}\right]$ methionine for $1-\mathrm{h}$ periods at different times after inoculation. Analyses of cleared cell lysates showed that synthesis of virus-specific proteins progressively replaced normal cellular protein synthesis as infection proceeded (Fig. 1). Infection always caused a significant reduction in the net incorporation of labeled amino acids, whereas at the same time a number of novel polypeptides appeared; the molecular weights of these polypeptides were estimated to be $150,000,54,000,26,500,25,500$, 24,000 , and 14,500 . They could be imniunoprecipitated with an antiserum obtaint $d$ frn mice that had survived an MHV-A59 infec . . $/ F$ ig. 1), as well as with a rabbit antiserum $r e$ against the viral structural proteins data not shown). The 51,000-dalton polypeptide (usually together with a 48,000 -dalton polypeptide) was generated by degradation from the 54,000 -dalton species, as described previously (6). Immunoprecipitates were not heated before electrophoresis 
virus

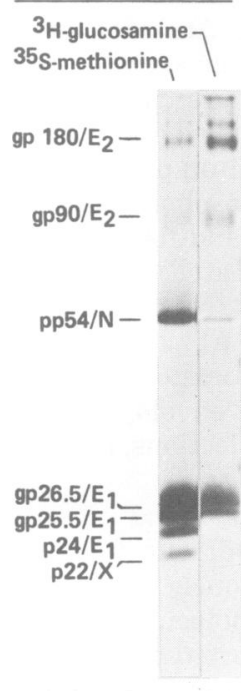

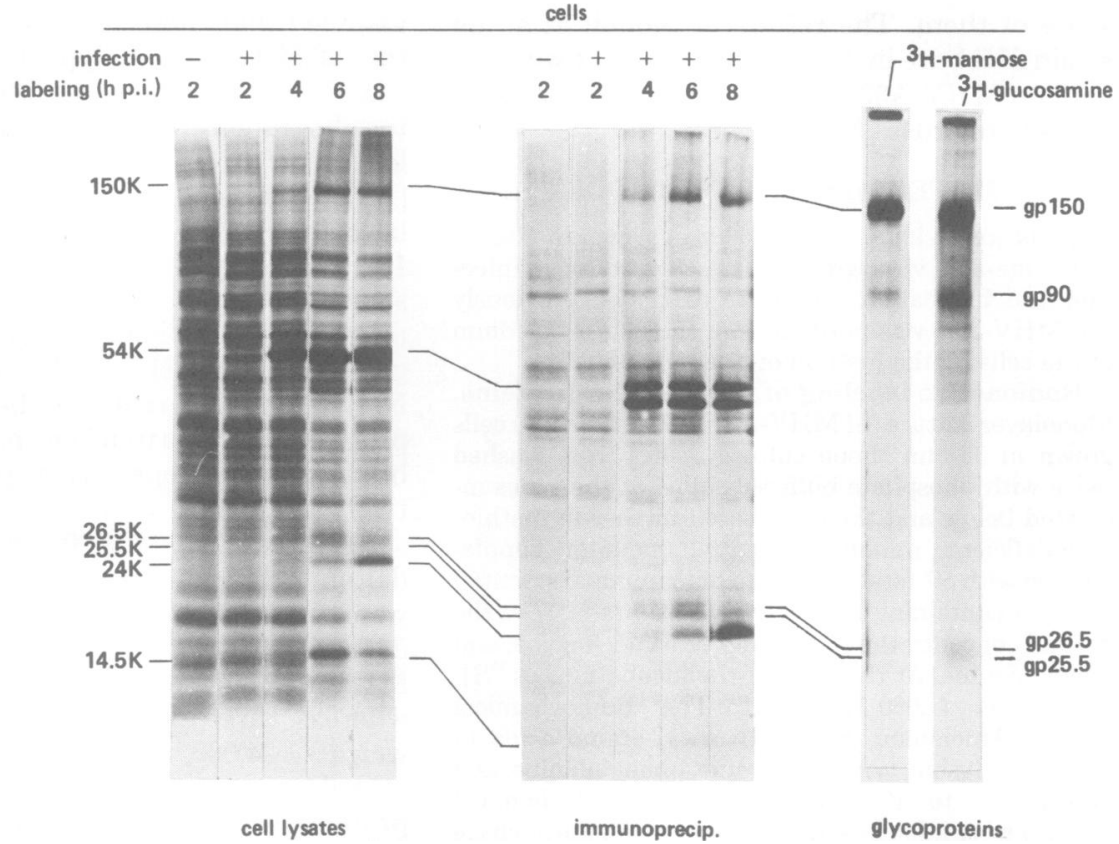

Fig. 1. Electrophoretic analysis of MHV-A59 structural proteins and proteins in MHV-A59-infected cells. Virus was purified from the culture fluids of infected Sac $(-)$ cells labeled with $\left.{ }^{35} \mathrm{~S}\right]$ methionine $(100 \mu \mathrm{Ci} / \mathrm{ml})$ and with $\left[{ }^{3} \mathrm{H}\right]$ glucosamine $(32 \mu \mathrm{Ci} / \mathrm{ml})$ at 3 to 8.5 and 3.5 to $10.5 \mathrm{~h}$ postinfection (p.i.), respectively. The virus samples were analyzed without prior heating. Proteins in MHV-A59-infected and mock-infected Sac $(-)$ cells were labeled with $25 \mu \mathrm{Ci}$ of $\left[^{35} \mathrm{~S}\right]$ methionine per $\mathrm{ml}$ for $1 \mathrm{~h}$ at the times indicated. Cell lysates were prepared, and samples $(150,000 \mathrm{cpm})$ were analyzed after they were heated for $4 \mathrm{~min}$ at $95^{\circ} \mathrm{C}$. Other samples were immunoprecipitated by using mouse anti-MHV-A59 serum as described previously (6), and precipitates originating from equal numbers of cells were electrophoresed similarly but without heating. MHV-A59-specific intracellular glycoproteins were labeled with $\left[{ }^{3} \mathrm{H}\right]$ mannose $(300 \mu \mathrm{Ci} / \mathrm{ml})$ or $\left[{ }^{3} \mathrm{H}\right] \mathrm{glucosamine}(500 \mu \mathrm{Ci} / \mathrm{ml})$ at 6 to $8 \mathrm{~h}$ postinfection. Cells were lysed, and samples of the lysates were heated for 4 min at $95^{\circ} \mathrm{C}$ in electrophoresis sample buffer. All analyses were done in $15 \%$ polyacrylamide gels.

since this caused aggregation of the 26,500-, 25,500 -, and 24,000 -dalton polypeptides. The $54,000-, 26,500-, 25,500$-, and 24,000 -dalton polypeptides but not the 150,000-dalton polypeptide comigrated with virion structural proteins (Fig. 1). All virus-specific intracellular proteins appeared simultaneously about 3 to $4 \mathrm{~h}$ postinfection, after which their rates of synthesis rapidly increased, in correspondence with the time course of accumulation of MHV-A59 extracellular infectivity (10). When MHV-A59-infected cells were incubated with $\left[{ }^{3} \mathrm{H}\right]$ mannose or $\left[{ }^{3} \mathrm{H}\right]$ glucosamine, the 150,000 -dalton polypeptide and a protein that had a molecular weight of about 90,000 and comigrated with MHV-A59 gp90/E2 were heavily labeled (Fig. 1). In addition, the 25,500- and 26,500-dalton species could be labeled with $\left[{ }^{3} \mathrm{H}\right]$ glucosamine but not with $\left[{ }^{3} \mathrm{H}\right]$ mannose.

Pulse-chase labeling of intracellular proteins. To investigate whether some of the MHVA59-specific intracellular proteins were subject to processing, infected cells,were pulse-labeled for 15 min with ${ }^{3} \mathrm{H}$-amino acids at $7 \mathrm{~h}$ postinfection, and the label was then chased for varying times. Electrophoresis of the immunoprecipitates of the postnuclear supernatants of the pulse-labeled cells prepared with rabbit antiserum produced the known set of MHV-A59-specific polypeptides, except for the 90,000 -dalton glycoprotein (Fig. 2). During the chase period the intensity of the gp150 band in the gel decreased, whereas a protein with the electrophoretic mobility of gp90/E2 appeared. No turnover of p54 (or p51 and p48) occurred, but a shift in the distribution of label among the lower-molecular-weight polypeptides was observed. After the pulse, more radioactivity was found in p24 than in gp25.5 or gp26.5. During the chase, however, inversion of the distribution of radioactivity took place, presumably as a result of glycosylation of the lower-molecular-weight polypeptide. In some experiments p24 was the only species labeled during the pulse, and gp25.5 and gp26.5 first appeared during the chase. Protein p22 was a stable species, and p14.5 was lacking 
in this experiment. Some other potentially virusspecific bands were visible in the autoradiograph (Fig. 2). These bands could not be demonstrated reproducibly with infected cells. They seemed to

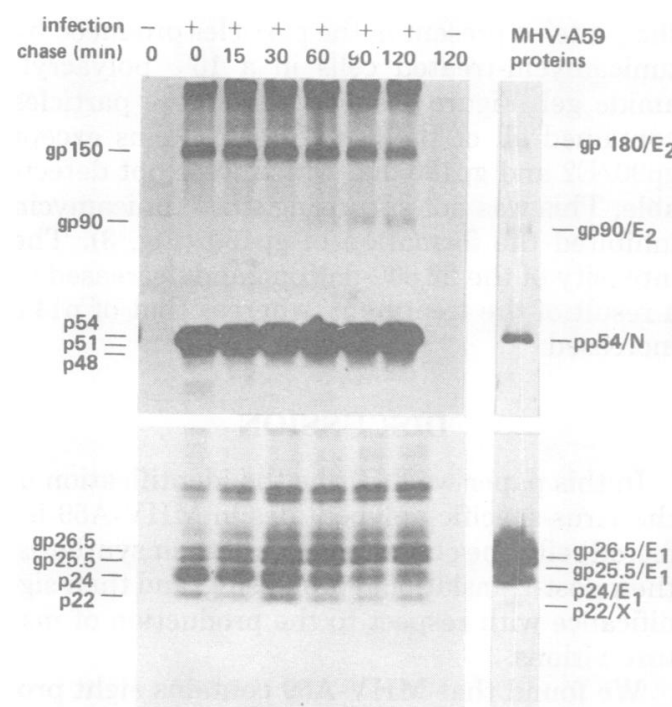

Fig. 2. Pulse-chase labeling of intracellular MHV-A59-specific proteins. MHV-A59-infected and mock-infected Sac(-) cells were pulse-labeled with ${ }^{3} \mathrm{H}$-amino acids $(100 \mu \mathrm{Ci} / \mathrm{ml})$ for $15 \mathrm{~min}$ at $7 \mathrm{~h}$ postinfection and chased with unlabeled medium for varying times. The cells were lysed, the lysates were immunoprecipitated with rabbit anti-MHV-A59 serum, and unheated samples of the precipitates were analyzed in polyacrylamide gels together with an unheated sample of purified ${ }^{3} \mathrm{H}$-amino acid-labeled virus. To show the resolution of both the highermolecular-weight proteins (gp180/E2 and gp150) and the lower-molecular-weight proteins, the upper part of a $12.5 \% \mathrm{gel}$ and the lower part of a $15 \%$ gel were combined. be stable polypeptides which were precipitable with antiserum against the viral structural proteins but which did not occur as such in viral particles. They might have been degradation products of one or more structural proteins.

Effect of tunicamycin on MHV-A59-specific protein synthesis, virus infectivity, and assembly. First, we determined the dose of tunicamycin required for complete inhibition of $\mathrm{N}$ glycosidical glycosylation. Parallel cultures of uninfected Sac(-) cells were incubated for 4 $h$ in the presence of varying concentrations of tunicamycin (a generous gift from R. L. Hamill, Lilly Research Laboratories, Indianapolis, Ind.), and then these cultures were labeled for $15 \mathrm{~min}$ with either ${ }^{3} \mathrm{H}$-amino acids or $\left[{ }^{3} \mathrm{H}\right]$ mannose. We found that concentrations of $0.5 \mu \mathrm{g} / \mathrm{ml}$ or higher completely inhibited incorporation of mannose, whereas overall protein synthesis was affected only moderately (Table 1). Preincubation for 4 $\mathrm{h}$ with $0.5 \mu \mathrm{g}$ of tunicamycin per $\mathrm{ml}$ was used in all further experiments. In MHV-A59-infected cells this treatment also abolished $\left[{ }^{3} \mathrm{H}\right]$ mannose incorporation, but protein synthesis (as measured by the appearance of $\left[{ }^{35} \mathrm{~S}\right]$ methionine in trichloroacetic acid-precipitable material) was slightly stimulated (Table 1).

When MHV-A59-infected Sac(-) cells were grown in the presence of tunicamycin, no syncytia developed. However, when intracellular protein synthesis was analyzed, we observed little effect of the drug; with one exception all virus-specific proteins appeared (Fig. 3), whereas host protein synthesis was shut off, as in untreated MHV-A59-infected cells (data not shown). The main change was that no gp150 was observed. Instead, a polypeptide with a molecular weight of about 110,000 appeared; this polypeptide could not be labeled by glucosamine or

TABLE 1. Effect of tunicamycin on the incorporation of amino acids and mannose in uninfected and MHV-A59-infected Sac(-) cells

\begin{tabular}{|c|c|c|c|c|}
\hline \multirow{2}{*}{ Cells } & \multirow{2}{*}{$\begin{array}{c}\text { Concn of } \\
\text { tunicamycin } \\
(\mu \mathrm{g} / \mathrm{ml})\end{array}$} & \multicolumn{3}{|c|}{ Incorporation (cpm) of: } \\
\hline & & ${ }^{3} \mathrm{H}$-amino acids & {$\left[{ }^{3} \mathrm{H}\right]$ mannose } & {$\left[{ }^{35} \mathrm{~S}\right]$ methionine } \\
\hline \multirow[t]{5}{*}{ Uninfected $^{a}$} & 0 & $45.1 \times 10^{4}(100)^{b}$ & $18.3 \times 10^{3}(100)$ & \\
\hline & 0.05 & $28.3 \times 10^{4}(63)$ & $4.0 \times 10^{3}(22)$ & \\
\hline & 0.5 & $27.9 \times 10^{4}(62)$ & $0(0)$ & \\
\hline & 2.0 & $28.0 \times 10^{4}(62)$ & $0(0)$ & \\
\hline & 5.0 & $27.6 \times 10^{4}(61)$ & $0(0)$ & \\
\hline \multirow[t]{2}{*}{ Infected $^{c}$} & 0 & & $36.5 \times 10^{5}(100)$ & $19.3 \times 10^{6}(100)$ \\
\hline & 0.5 & & $0.5 \times 10^{5}(1.4)$ & $21.4 \times 10^{6}(111)$ \\
\hline
\end{tabular}

\footnotetext{
${ }^{a}$ Cultures of Sac(-) cells grown in $35-\mathrm{mm}$ plastic dishes were incubated with tunicamycin at different concentrations. The cells were labeled $4 \mathrm{~h}$ later for $15 \mathrm{~min}$ with either ${ }^{3} \mathrm{H}$-amino acids $(5 \mu \mathrm{Ci} / \mathrm{ml})$ or $\left[{ }^{3} \mathrm{H}\right] \mathrm{mannose}$ $(24 \mu \mathrm{Ci} / \mathrm{ml})$. Trichloroacetic acid-precipitable radioactivity was determined in cell lysates.

${ }^{b}$ Numbers in parentheses are percentages.

${ }^{c}$ Cultures of MHV-A59-infected Sac(-) cells were incubated in 35-mm plastic dishes in the absence or in the presence of tunicamycin $(0.5 \mu \mathrm{g} / \mathrm{ml})$, which was added at $2 \mathrm{~h}$ postinfection. At $6 \mathrm{~h}$ postinfection the cells were labeled for $2 \mathrm{~h}$ with either $\left[{ }^{35} \mathrm{~S}\right]$ methionine $(25 \mu \mathrm{Ci} / \mathrm{ml})$ or $\left[{ }^{3} \mathrm{H}\right]$ mannose $(300 \mu \mathrm{Ci} / \mathrm{ml})$. Finally, the incorporation of the label was assayed by measuring trichloroacetic acid-precipitable radioactivity in cell lysates.
} 
mannose, suggesting that it was the unglycosylated precursor of gp150. This 110,000-dalton polypeptide was probably unstable since it disappeared during a chase (Fig. 3). Surprisingly, the syntheses of the other two virus-specific glycoproteins (gp25.5 and gp26.5) were not affected by tunicamycin. Although these proteins were hardly detectable in tunicamycin-treated cells after a 15-min pulse with ${ }^{3} \mathrm{H}$-amino acids in this experiment, they were evident after the chase. Obviously, their carbohydrate moieties were not linked to the polypeptides through $\mathbf{N}$ glycosidical bonds. These results were in accordance with the inhibition of mannose incorporation by tunicamycin (Table 1), since gp25.5 and gp26.5 lacked this sugar and contained glucosamine (Fig. 1). Tunicamycin treatment of infected cells reduced the incorporation of $\left[{ }^{3} \mathrm{H}\right]$ mannose to about $2 \%$, whereas $\left[{ }^{3} \mathrm{H}\right]$ glucosamine incorporation still attained approximately $24 \%$ of the level in the control cells, as determined in one experiment.

Tunicamycin reduced the yields of extracellular infectious virus by more than $99 \%$. When standard virus purification procedures were used with the medium from tunicamycin-treated cells labeled with $\left[{ }^{35} \mathrm{~S}\right]$ methionine, it appeared that radioactivity banded in the sucrose density gra-

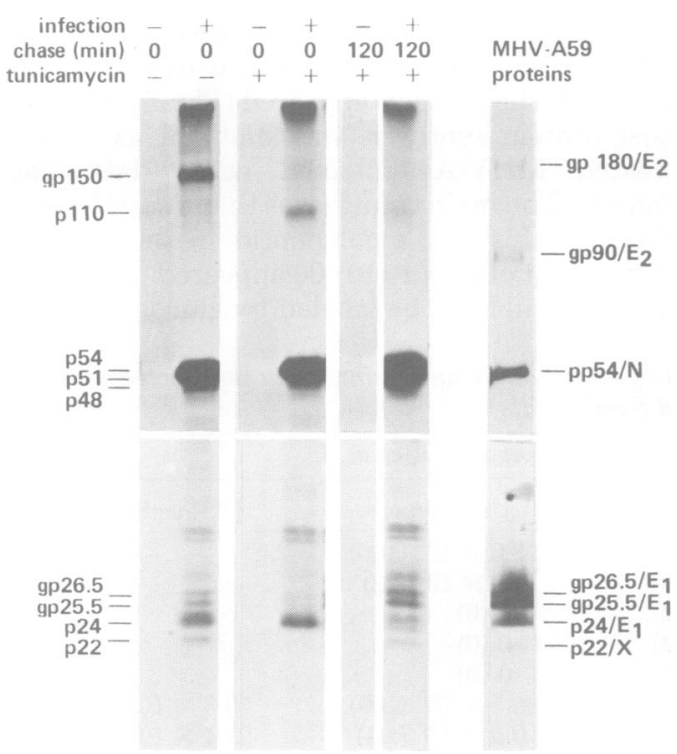

Fig. 3. Effect of tunicamycin on virus-specific intracellular proteins. MHV-A59-infected and mock-infected Sac(-) cells were incubated in the absence or in the presence of tunicamycin $(0.5 \mu \mathrm{g} / \mathrm{ml})$; when used, this antibiotic was present from $3 \mathrm{~h}$ postinfection. Pulse-labeling, chasing, and analysis of virus-specific proteins were performed as described in the legend to Fig. 2. dient at about the position where normal MHVA59 particles accumulated. The yield of this radioactivity was usually of the same order of magnitude as the amount of label in virions obtained from untreated controls. We analyzed the proteins present in the particles produced by tunicamycin-treated cells in a $15 \%$ polyacrylamide gel. Figure 4 shows that these particles contained all of the structural proteins except gp90/E2 and gp180/E2, which were not detectable. This was not surprising since tunicamycin inhibited the formation of gp150 (Fig. 3). The intensity of the 22,000-dalton band decreased as a result of the treatment, whereas that of p14.5 increased.

\section{DISCUSSION}

In this paper we describe the identification of the virus-specific polypeptides in MHV-A59-infected cells, the characteristics of their synthesis, their post-translational processing, and their significance with respect to the production of mature virions.

We found that MHV-A59 contains eight proteins. These were designated gp180/E2, gp90/

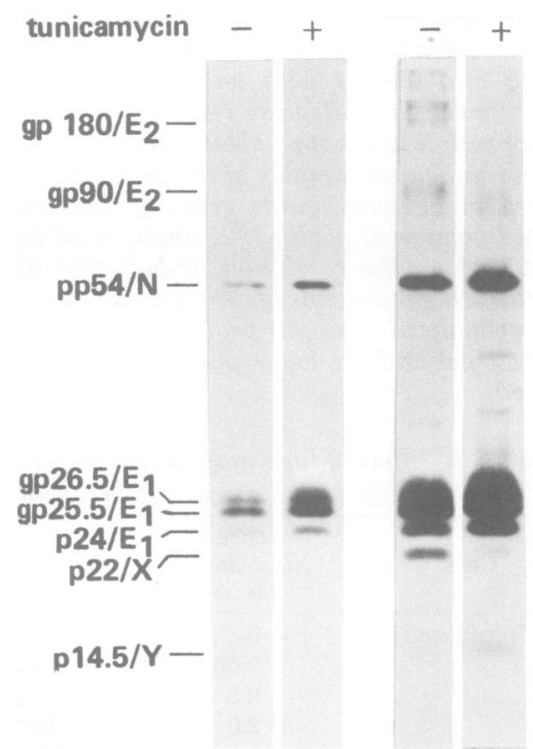

Fig. 4. Effect of tunicamycin on MHV-A59 structural proteins. Two cultures of MHV-A59-infected Sac(-) cells were labeled with $\left[{ }^{35}\right.$ S]methionine (100 $\mu \mathrm{Ci} / \mathrm{ml}$ ) at 3 to $8.5 \mathrm{~h}$ postinfection. One culture contained tunicamycin $(0.5 \mu \mathrm{g} / \mathrm{ml})$ from $1 \mathrm{~h}$ postinfection through the rest of the incubation. Viral particles were isolated from the culture media (10) and ana lyzed without heating in a $15 \%$ polyacrylamide gel. Autoradiographs of the electrophoretic patterns of both preparations after two different times of exposure are shown. 
$\mathrm{E} 2, \mathrm{pp} 54 / \mathrm{N}, \mathrm{gp} 26.5 / \mathrm{E} 1, \mathrm{gp} 25.5 / \mathrm{E} 1, \mathrm{p} 24 / \mathrm{E} 1, \mathrm{p} 22 /$ $\mathrm{X}$, and $\mathrm{p} 14.5 / \mathrm{Y}$, indicating the size of each protein, the presence and nature of the prosthetic group, and the location in virions; these designations extended the terminology introduced by Sturman and Holmes (17). The positions of the 22,000 - and 14,500-dalton species in virus particles are unknown. Our findings are essentially in agreement with data reported by others $(2,13$, 16-18), except for the lower-molecular-weight polypeptides. Only one MHV-A59 E1 glycoprotein has been described previously, whereas we observed three. Of these polypeptides, the two larger ones could be labeled with $\left[{ }^{3} \mathrm{H}\right]$ glucosamine, and none could be labeled with $\left[{ }^{3} \mathrm{H}\right] \mathrm{man}$ nose. Analyses of purified MHV-A59 in 15\% polyacrylamide gels allowed the detection of a hitherto unidentified 14,500-dalton polypeptide. A protein species of comparable size was observed recently in cells infected with MHV strain JHM but not in purified preparations of this virus (9).

In general, the protein composition of strain JHM agrees with that of strain A59 except for a 65,000-dalton strain JHM glycoprotein not found in strain A59 and the 22,000-dalton protein not found in strain JHM (9). A comparison of our data with previously published data on other coronaviruses has been hampered by the seemingly large variability in protein composition (5). However, these differences may not be real; rather, they may reflect the effects of variations in the analytical techniques used.

Infection of Sac(-) cells with MHV-A59 induces the synthesis of several virus-specific polypeptides, which have been designated gp150, gp90, p54, gp26.5, gp25.5, p24, p22, and p14.5. The virus specificity of these polypeptides was established by immunoprecipitation. The most abundant protein in MHV-A59-infected cells during all stages of infection is p54, which can be detected even in crude cell lysates. Upon immunoprecipitation, products with molecular weights of about 51,000 and 48,000 are formed; this is also true with the viral nucleocapsid protein (6). These properties suggest that $\mathrm{p} 54$ is identical to $\mathrm{pp} 54 / \mathrm{N}$, the primary translation product of subgenomic viral mRNA 7 (6).

Another major intracellular virus-specific polypeptide is gp150. This polypeptide is composed of one or more mannose- and glucosamine-containing carbohydrate units which are $\mathrm{N}$ glycosidically linked to a 110,000 -dalton polypeptide, as shown by the accumulation of the unglycosylated core polypeptide in the presence of tunicamycin. In a previous paper we argued that $\mathrm{gp} 150$ is encoded by subgenomic viral mRNA 3 (6). The ability of an antiserum raised against pure MHV-A59 to precipitate gp150 in- dicated a precursor function for one of the structural proteins. Support for this hypothesis was obtained from pulse-chase experiments that demonstrated the processing of gp150 and the concomitant appearance of gp90. Most likely this glycoprotein is incorporated as such into virions and is identical to gp90/E2. No intracellular species corresponding to gp180/E2 has been detected. Sturman and Holmes (17) have shown that the two MHV-A59 E2 species have identical tryptic peptide maps. Two possible routes for the synthesis of these species were considered; either gp90/E2 is a product of proteolytic cleavage of $\mathrm{gp} 180 / \mathrm{E} 2$, or the latter arises by dimerization of $\mathrm{gp} 90 / \mathrm{E} 2$. We think that at some stage during virus assembly gp90 associates to form its dimer, gp180/E2, which is in agreement with the conclusion from work with strain JHM-infected cells (9). In addition to the processing of the 150,000-dalton precursor into the smaller virion peplomer protein, Siddell et al. (9) also observed the appearance of the larger peplomer protein. One possible explanation for the low level of gp90 in MHV-A59-infected cells and for our inability to detect intracellular gp180 is that these polypeptides are cleared from the cells rapidly as a result of virus release. The fate of the approximately 60,000-dalton moiety which also results from the cleavage of gp150 is not known.

Proteins p24, gp25.5, and gp26.5 in MHV-A59infected cells are most probably identical to the protein species found in the viral envelope. This hypothesis is based on several lines of evidence. First, these proteins have the same molecular weights. Second, their sugar moieties can be labeled with glucosamine but not with mannose. Third, the syntheses of both the intracellular glycoproteins and the virion glycoproteins are resistant to tunicamycin. Since this antibiotic specifically blocks the formation of protein-carbohydrate linkages of the $\mathrm{N}$ glycosidic type (15, 19), the sugar residues in these glycoproteins are apparently linked to the polypeptide core through $\mathrm{O}$ glycosidic bonds. Fourth, both the intracellular species and the virion species aggregate upon heating in sodium dodecyl sulfate, as described by Sturman (16) for the MHV-A59 envelope protein. Our pulse-chase experiments indicated that the three $\mathrm{E} 1$ species may possess a common polypeptide moiety but differ in the degree of glycosylation; label incorporated into p24 during a pulse with radioactive amino acids was chased into gp25.5 and gp26.5. Further support for this hypothesis was obtained by translation of the MHV-A59-specific subgenomic RNA 6 in Xenopus laevis oocytes into three polypeptides that comigrated with the $\mathrm{E} 1$ virion proteins (6). Since it has been demonstrated 


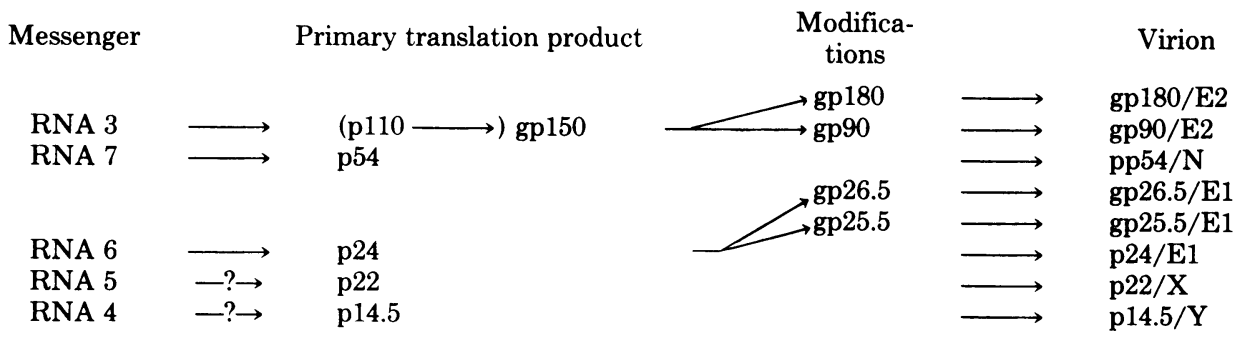

FIG. 5. Schematic representation of the synthetic pathways of MHV-A59 structural proteins.

recently that the nucleotide sequence of RNA 7 is contained in RNA 6 (W. J. M. Spaan, P. J. M. Rottier, M. C. Horzinek, and B. A. M. van der Zeijst, manuscript in preparation), these products are most likely translated from the nonoverlapping 300,000-dalton region, which is sufficient for one protein species of up to 30,000 daltons.

Based upon the results described here and in a preceding paper (6) and by analogy to data obtained with strain JHM (9), the synthesis of MHV-A59 structural proteins can be described as follows (Fig. 5). p54, p24, p22, and p14.5 are primary translation products that are incorporated into virions without appreciable modifications. In contrast, the other virion proteins arise by post-translational modification. In ovo translation allowed the assignment of gp150, p54, and p24/gp25.5/gp26.5 to subgenomic mRNA's 3,7 , and 6 , respectively (6), in agreement with our model of the coronaviral translation strategy (10). Similarly, RNAs 5 and 4 are the probable messengers for p22 and p14.5, respectively. Consequently, the combined information for the structural proteins of MHV-A59 is clustered in the $3^{\prime}$ portion of the viral genome.

Tunicamycin inhibited the production of infectious MHV-A59. Nevertheless, viral particles continued to be released, but these particles were deficient in gp90/E2 and gp180/E2, as well as in p110, the intracellular precursor of gp90/ E2 and gp180/E2. Either the unglycosylated protein p110 is not assembled into viral particles, or it is degraded later on due to its sensitivity to proteolytic degradation (Fig. 4). Since gp90/E2 and gp180/E2 form the virion peplomers (1618), we anticipate that particles produced under such conditions should lack the surface projections which are obviously essential for infectivity but not for the maturation of viral particles. A comparable situation has been described for some other viruses $(3,4,7,14)$.

\section{ADDENDUM IN PROOF}

Our results on the effect of tunicamycin on the virion polypeptides of MHV-A59 are in close agree- ment with data reported by K. Holmes, L. Sturman, H. Niemann, and H.-D. Klenk. These investigators also observed the resistance of the glycosylation of the small envelope glycoprotein to tunicamycin (in $\mathrm{V}$. ter Meulen, S. Siddell, and H. Wege ed., The Biochemistry and Biology of Coronaviruses, in press). Sturman showed that virus particles lacking the peplomeric glycoprotein were shed by tunicamycin-treated MHVA59-infected cells. In addition, Holmes has investigated such particles electron microscopically. They lacked spikes and had very poor infectivity. A detailed study of the incorporation of radioactive sugars into MHV-A59 glycoproteins, the differential effect of tunicamycin, and the sugar composition of the glycoproteins led Niemann and Klenk to the concept of 0 glycosidic linkages in the small envelope glycoprotein, in contrast to the $\mathrm{N}$ glycosidic linkage in the peplomeric protein.

\section{ACKNOWLEDGMENT}

We thank M. Maas Geesteranus for the preparation of the manuscript.

\section{LITERATURE CITED}

1. Anderson, R., S. Cheley, and E. Haworth-Hatherell 1979. Comparison of polypeptides of two strains of murine hepatitis virus. Virology 97:492-494.

2. Bond, C. W., J. L. Leibowitz, and J. A. Robb. 1979. Pathogenic murine coronaviruses. II. Characterization of virus-specific proteins of murine coronaviruses JHMV and A59V. Virology 94:371-384.

3. Maheshwari, R. K., D. K. Banerjee, C. J. Waechter, K. Olden, and R. M. Friedman. 1980. Interferon treatment inhibits glycosylation of a viral protein. $\mathrm{Na}$ ture (London) 287:454-456.

4. Nakamura, K., and R. W. Compans. 1978. Effects of glucosamine, 2-deoxyglucose, and tunicamycin on glycosylation, sulfation, and assembly of influenza viral proteins. Virology 84:303-319.

5. Robb, J. A., and C. W. Bond. 1979. Coronaviridae, p. 193-247. In H. Fraenkel-Conrat and R. R. Wagner (ed.), Comprehensive virology, vol. 14. Plenum Press, New York.

6. Rottier, P. J. M., W. J. M. Spaan, M. C. Horzinek, and B. A. M. van der Zeijst. 1981. Translation of three mouse hepatitis virus strain A59 subgenomic RNAs in Xenopus laevis oocytes. J. Virol. 38:20-26.

7. Schwarz, R. T., J. M. Rohrschneider, and M. F. G. Schmidt. 1976. Suppression of glycoprotein formation of Semliki Forest, influenza, and avian sarcoma virus by tunicamycin. J. Virol. 19:782-791.

8. Siddell, S. G., H. Wege, A. Barthel, and V.ter Meulen. 1980. Coronavirus JHM: cell-free synthesis of structural protein p60. J. Virol. 33:10-17. 
9. Siddell, S. G., H. Wege, A. Barthel, and V.ter Meulen. 1981. Coronavirus JHM: intracellular protein synthesis. J. Gen. Virol. 53:145-155.

10. Spaan, W. J. M., P. J. M. Rottier, M. C. Horzinek, and B. A. M. van der Zeijst. 1981. Isolation and identification of virus-specific mRNAs in cells infected with mouse hepatitis virus (MHV-A59). Virology 108:424434.

11. Stern, D. F., and S. I. T. Kennedy. 1980. Coronavirus multiplication strategy. I. Identification and characterization of virus-specified RNA. J. Virol. 34:665-674.

12. Stern, D. F., and S. I. T. Kennedy. 1980. Coronavirus multiplication strategy. II. Mapping the avian infectious bronchitis virus intracellular RNA species to the genome. J. Virol. 36:440-449.

13. Stohlman, S. A., and M. M. C. Lai. 1979. Phosphoproteins of murine hepatitis viruses. J. Virol. 32:672-675.

14. Stohrer, R., and E. Hunter. 1979. Inhibition of Rous sarcoma virus replication by 2-deoxyglucose and tunicamycin: identification of an unglycosylated env gene product. J. Virol. 32:412-419.

15. Struck, D. K., and W. S. Lennarz. 1977. Evidence for the participation of saccharide-lipids in the synthesis of the oligosaccharide chain of ovalbumin. J. Biol. Chem. 252: 1007-1013.

16. Sturman, L. S. 1977. Characterization of a coronavirus. I. Structural proteins: effects of preparative conditions on the migration of protein in polyacrylamide gels. Virology 77:637-649.

17. Sturman, L. S., and K. V. Holmes. 1977. Characterization of a coronavirus. II. Glycoproteins of the viral envelope: tryptic peptide analysis. Virology 77:650-660.

18. Sturman, L. S., K. V. Holmes, and J. Behnke. 1980. Isolation of coronavirus envelope glycoproteins and interaction with the viral nucleocapsid. J. Virol. 33:449462.

19. Takatsuki, A., K. Kohno, and G. Tamura. 1975. Inhibition of biosynthesis of polyisoprenol sugars in chick embryo microsomes by tunicamycin. Agric. Biol. Chem. 39:2089-2091. 